\title{
Kemampuan Berpikir Kreatif Matematis dengan Menggunakan Education Game Berbantuan Android pada Barisan dan Deret
}

\author{
Asri Muslim Sanusi ${ }^{*}$, Ari Septian², dan Sarah Inayah ${ }^{3}$ \\ Program Studi Pendidikan matematika, Universitas Suryakancana \\ Jalan Dr. Muwardi Komplek Pasir Gede Raya, Cianjur, Jawa Barat, Indonesia

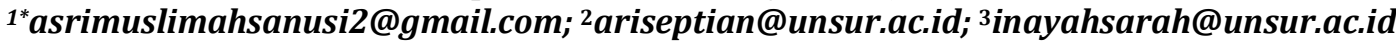

Artikel diterima: 03-08-2020, direvisi: 27-09-2020, diterbitkan: 30-09-2020

\begin{abstract}
Abstrak
Permasalahan yang melatarbelakangi penelitian ini yaitu karena masih rendahnya kemampuan berpikir kreatif matematis siswa. Tujuan penelitian ini untuk mengetahui apakah bantuan media pembelajaran education game yang juga sebagai alternatif solusi permasalahan dapat meningkatkan kemampuan berpikir kreatif matematis siswa. Kuasi eksperimen dengan desain Nonequivalent group pretest-postest design menjadi metode penelitian ini. Instrumen tes berbentuk essai tentang literasi matematis, berupa pretest dan posttest. Seluruh siswa kelas XI MAN 1 Cianjur pada tahun ajaran 2019/2020 menjadi populasinya, sedangkan sampelnya dipilih melalui teknik purposive sampling yaitu kelas XI MIPA 4 sebanyak 25 siswa sebagai kelas eksperimen yang diberikan perlakuan dengan menggunakan education game berbantuan android dan XI MIPA 3 sebanyak 25 siswa sebagai kelas kontrol dengan pembelajaran biasa. Hasilnya, peningkatan kemampuan berpikir kreatif matematis siswa dengan education game berbantuan android lebih baik dibandingkan dengan peningkatan pada siswa dengan pembelajaran biasa.

Kata Kunci: Education game, Kemampuan berpikir kreatif, Media.
\end{abstract}

\section{Mathematical Creative Thinking Ability Using Education Game Android Assisted on Sequence and Series}

\begin{abstract}
This study aims to determine whether the help of education game learning media which is also an alternative solution to problems can improve students' mathematical creative thinking abilities. The research method used was a quasi-experimental design with a Nonequivalent roup pretest-posttest design. The instruments are in the form of a mathematical literacy test in the form of a pre-test and a post-test. The population of this research was all students of class XI MAN 1 Cianjur in the academic year 2019/2020 which were spread out in eleven classes, while the sample was selected by using two purposive sampling techniques, namely class XI MIPA 4 as many as 25 students as an experimental class who were treated using media assistance learning educational games and Mathematics and Natural Sciences 3 as many as 25 students as a control class with ordinary learning. The result is the increase in students' mathematical creative thinking abilities with educational game android asssisted is better than the increase in students with ordinary learning.

Keywords: Education game, Creative thinking ability, Media.
\end{abstract}

Mosharafa: Jumal Pendidikan Matematika 


\section{Pendahuluan}

Era teknologi menjadi hal yang penting dalam dunia pembelajaran di masa kini (Latifah \& Madio, 2014; Suryadi, 2015; Restiana \& Pujiastuti, 2019). Kemajuan jaman memerlukan adaptasi dari para pendidik dalam mengembangkan kualitas mengajarnya. Era digital dengan berbagai media yang digunakan sangat penting dalam bidang pendidikan.

Dalam menghadapi era revolusi abad ke XXI diperlukan pendidikan yang membentuk pelajar yang kreatifitasnya tinggi, inovatif, serta bersaing (Lestari \& Sofyan, 2013; Pitriani \& Afriansyah, 2017; Nopiyani, Turmudi, \& Prabawanto, 2018). Sehingga optimalisasi dalam menggunakan teknologi sebagai media menjadi solusi permasalahan dunia pendidikan. Misalnya pemanfaatan smartphone.

Smartphone memiliki keunggulan yang dapat digunakan untuk menunjang berbagai pembelajaran, diantaranya pelajaran matematika yang selama ini dianggap kurang menarik. Dengan alat bantu smartphone, belajar metematika dipandang akan lebih bermakna. Terdapat berbagai software pembuat media pembelajaran di antaranya Adobe Flash, Construct, RPG maker, dan quizizz (Hendriawan \& Septian, 2019; Rahmawati, 2018). Software tersebut juga mempermudah guru menyampaikan materi pelajaran (Afriansyah, 2016; Hader, 2017). Perbedaan dan kebaruan yang ada dalam penelitian ini yaitu penggunaan android dalam materi barisan dan deret serta modifikasi bentuk game education.

Kesulitan siswa dalam pelajaran matematika menjadi salah satu yang utama dalam permasalahan pendidikan (Sulastri \& Haq, 2013; Mayasari \& Afriansyah, 2016;
Suwarto, 2018; Inayah, Septian, \& Suwarman, 2020). Menurut Permendikbud Nomor 81A tentang Implementasi Kurikulum, diuraikan bahwa kemampuan berkomunikasi, berpikir kritis, dan berpikir kreatif siswa diperlukan dalam pembelajaran (Kementerian Pendidikan dan Kebudayaan Republik Indonesia, 2013). Penting bagi seorang siswa memiliki kemampuan berpikir kreatif dalam belajar matematika sehingga akan lebih mudah dalam memahami masalah nyata (Suripah, 2017; Nurhikmayati \& Sunendar, 2020).

Kemampuan berpikir kreatif matematis siswa masih rendah (Haq, 2012; Permatasari \& Margana, 2014; Tarlina \& Afriansyah, 2016; Febriani \& Ratu, 2018). Pernyataan ini di perkuat berdasarkan hasil Survey di lapangan Programme for International Student Assessment (PISA) di tahun 2018. Hal ini menunjukkan bahwa Indonesia masih tergolong rendah dalam penguasaan materi dan rendahnya kemampuan berpikir kreatif siswa dalam menyelesaikan soal PISA.

Permasalahan kemampuan berpikir kreatif siswa di sekolah yang masih rendah diakibatkan oleh pemberian tugas dan cara mengajar guru yang belum variatif (Fu'adiah, 2016; Pamungkas \& Afriansyah, 2017; Muhammad, Septian, \& Sofa, 2018; Pangestu \& Yunianta, 2019). Diperlukan media pembelajaran dengan menggunakan teknologi (Hockly, 2013; Nadz, 2013; Tarusu, 2018; Dewi \& Afriansyah, 2018; Lisnani \& Pranoto, 2020; Septian, Darhim, \& Prabawanto, 2020). Strategi dalam mengajarkan bagaimana siswa memahami sekaligus membuat menyenangkan merupakan kombinasi menarik sehingga harapannya yaitu siswa dapat dengan mudah memahami materi.

Media pembelajaran dipandang menjadi alternatif penyelesaian masalah pembelajaran 
di kelas (Sugilar, 2013; Afriansyah, 2015; Florayu, Isnaini, \& Testiana, 2017; Firdausi \& Asikin, 2018; Hodiyanto, Darma, \& Putra, 2020). Dengan memanfaatkan media pembelajaran, kemampuan berpikir kreatif pada pelajaran matematika menjadi meningkat dan membantu guru dalam mengatasi kesulitan siswa.

Selain dengan berbantuan media pembelajaran, peningkatan kemampuan berpikir kreatif siswa dapat dicapai melalui education game (Kidi, dkk., 2017; Komariah \& Sudayana, 2017 Pramuditya, Noto, \& Purwono, 2018; Mardiani, 2018). Hal tersebut dapat meningkatkan pola pikir kreatif serta menambah pengetahuan dan hasil belajar siswa.

Berdasarkan uraian yang telah dikemukakan, diharapkan penelitian ini dapat mempermudah guru dalam menyampaikan materi dan dapat meningkatkan kemampuan berpikir kreatif matematis siswa.

\section{Metode}

Kuasi eksperimen menjadi metode penelitian ini dengan pendekatan kuantitatif, yaitu metode yang digunakan untuk melihat suatu pengaruh model pembelajaran (Sugiyono 2013). Penelitian ini dilaksanakan kurang lebih tiga minggu dengan jumlah lima kali pertemuan pada tanggal 12 februari sampai 28 februari 2020. Tempat penelitian di MAN 1 Cianjur dengan populasi seluruh siswa kelas XI. 25 siswa dari Kelas XI MIPA 4 sebagai kelas eksperimen dan 25 siswa dari kelas XI MIPA 3 sebagai kelas kontrol sebagai Sampelnya.

Kelas eksperimen diberikan treatment atau perlakukan khusus dengan educatian game berbasis android, sedangkan kelas kontrol dengan pembelajaran biasa. Kedua kelas akan diberikan tes berupa pretest untuk mengetahui keadaan sebelumnya. Terakhir kedua kelas akan diberikan posttest.

Nonequivalent group pretest-postest menjadi desain dalam penelitian ini. Instrumennya menggunakan tes kemampuan berpikir kreatif yang terdiri dari tes awal dan tes akhir. Bentuk dari tes merupakan tes uraian yang terdiri dari 5 butir,contoh soalnya seperti pada gambar 1.

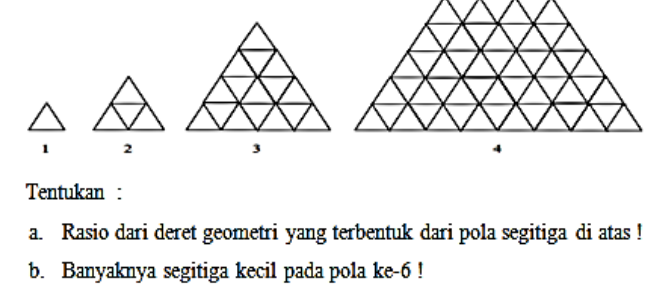

Gambar 1. Contoh Soal Tes Kemampuan Berpikir Kreatif

Soal tersebut sebelumnya sudah di ujikan pada 30 siswa kelas XII, setelah dilakukan uji coba, data tersebut diolah dengan mengukur validitas, reliabilitas, daya pembeda serta tingkat kesukaran. Instrumen tes mencapai tingkat validitas tinggi dan reliabel sehingga dapat digunakan. Analisis data pretes dan indeks gain yaitu dengan menggunakan uji normalitas serta pengujian menggunakan uji Mann Whitney.

\section{Hasil dan Pembahasan}

A. Hasil Penelitian

1. Analisis data pretest

Pengolahan data pretest dilakukan dengan menggunakan software SPSS 22.

Tabel 1.

Deskripsi statistik skor pretest

\begin{tabular}{ccc}
\hline Kelas & Eksperimen & Kontrol \\
\hline Rata-rata & 7,52 & 6,28
\end{tabular}




\begin{tabular}{|ccc|}
\hline Std. Deviasi & 1,982 & 2,189 \\
\hline Minimum & 3 & 2 \\
\hline Maximum & 13 & 10 \\
\hline
\end{tabular}

Berdasarkan Tabel 1, rata-rata skor pretest kelas eksperimen adalah 7,52 dan standar deviasi 1,982. Sedangkan kelas kontrol diperoleh rata-rata 6,28 dan standar deviasi 2,189 . Nilai pretest terendah kelas eksperimen adalah 3 dan tertingginya 13, sedangkan nilai pretest terendah kelas kontrol adalah 2 dan tertingginya 10 . Dari deskripsi data tersebut terlihat bahwa skor rata-rata kelas eksperimen lebih tinggi dibandingkan skor rata-rata kelas kontrol, serta selisih rata-ratanya 1,24. Namun demikian, untuk mengetahui apakah kemampuan awal berpikir kreatif matematis sama atau tidak, maka nilai pretest kelas eksperimen dan kelas kontrol harus diuji dengan uji statistik berikut.

a. Uji Normalitas Data Pretest

Uji normalitas dalam penelitian ini menggunakan test of normality dari Shapiro Wilk dengan SPSS 22 dimana taraf signifikasinya yaitu $5 \%(0,05)$. Kriteria uji normalitas adalah $H_{0}$ diterima jika nilai sig. $\geq$ 0,05 dan $H_{0}$ ditolak jika nilai sig. < 0,05. Adapun hasil pengolahan data dengan test of normality dari ShapiroWilk sebagai berikut:

Tabel 2.

Hasil Uji Normalitas Distribusi Populasi Data Pretest

\begin{tabular}{|lcl|}
\hline \multicolumn{1}{c}{ Kelas } & \multicolumn{1}{c}{ ShapiroWilk } \\
\cline { 2 - 3 } \multicolumn{1}{c|}{ Eksperimen } & 0,042 & \multicolumn{1}{c|}{ Keterangan } \\
Data pretest berdistribusi \\
tidak normal. \\
Kontrol & 0,008 & $\begin{array}{l}\text { Data pretest berdistribusi } \\
\text { normal. }\end{array}$ \\
\hline
\end{tabular}

Berdasarkan hasil uji normalitas distribusi populasi yang terdapat pada Tabel. 4.2 diperoleh nilai signifikansi untuk kelas eksperimen sebesar 0,042. Karena nilai signifikansi kelas ekperimen kurang dari 0,05 maka $H_{0}$ ditolak, kesimpulannya sampel kelas eksperimen tidak berdistribusi normal.
Sedangkan untuk kelas kontrol memperoleh nilai signifikansi sebesar 0,008, karena nilai signifikansi kelas kontrol lebih dari 0,05 maka $H_{0}$ diterima, kesimpulannya sampel kelas kontrol berdistribusi normal, maka analisis data dilanjutkan dengan uji mann-whitney dengan menggunakan software SPSS 22.

b. Uji Mann-Whitney Data Pretest

Uji Mann-Whitney dalam penelitian ini menggunakan SPSS 22 dimana taraf signifikasinya yaitu 5\% $(0,05)$. Tujuan dilakukannya uji Mann-Whitney yaitu untuk melihat apakah kemampuan berpikir kreatif matematis awal siswa sama atau tidak. Adapun perumusan hipotesis untuk uji MannWhitney, sebagai berikut:

Kriteria uji Mann-Whitney adalah $H_{0}$ diterima jika nilai sig. $\geq 0,05$ dan $H_{0}$ ditolak jika nilai sig. $<0,05$. Adapun hasil pengolahan data Mann-Whitney sebagai berikut:

Tabel 3.

Hasil Mann-Whitney Distribusi Populasi Data Pretest

\begin{tabular}{cl}
\multicolumn{2}{c}{ Pretest } \\
\hline Asymp. Sig. (2-tailed) & Keterangan \\
\hline 0,066 & $H_{0}$ diterima
\end{tabular}

Berdasarkan hasil uji Mann-Whitney pada Tabel 3, diperoleh nilai signifikansi untuk Asymp. Sig. (2-tailed) sebesar 0,066 atau lebih dari 0,05 maka $H_{0}$ diterima. Kesimpulannya, kemampuan awal berpikir kreatif matematis siswa kelas eksperimen dan kelas kontrol sama.

2. Analisis data indeks gain

Analisis data indeks gain dilakukan untuk mengetahui rata-rata peningkatan dari kemampuan berpikir kreatif matematis siswa kelas eksperimen dan kelas kontrol. Selanjutnya, dilakukan analisis deskriptif data indeks gain dilakukan dengan menggunakan SPSS 22. Berikut hasil analisis statistik deskriptif data indeks gain kelas eksperimen dan kelas kontrol. 
Tabel 4.

Statistik Deskriptif Data indeks gain

\begin{tabular}{|ccc|}
\hline Kelas & Eksperimen & Kontrol \\
\hline Rata-rata & 0,6784 & 0,5312 \\
\hline Std. Deviasi & 0,12896 & 0,19529 \\
\hline Minimum & 0,29 & $-0,27$ \\
\hline Maximum & 0,92 & 0,69 \\
\hline
\end{tabular}

Berdasarkan Tabel 4, rata-rata indeks gain kelas eksperimen adalah 0,6784 dan standar deviasi 0,12896. Sedangkan untuk kelas kontrol diperoleh rata-rata 0,5312 dan standar deviasi 0,19529. Kesimpulannya, nilai rata-rata indeks gain kelas ekperimen lebih tinggi dari pada rata-rata indeks gain kelas kontrol.

Namun untuk mendapatkan hasil yang lebih objektif dan untuk mengetahui apakah perbedaan rata-rata indeks gain tersebut signifikan atau tidak, maka data akan indeks gain kedua kelas harus diuji dengan uji statistik sebagai berikut:

a. Uji Normalitas Data Indeks Gain

Uji normalitas digunakan untuk mengetahui apakah indeks gain yang diperoleh dari kedua kelas tersebut berdistribusi normal atau tidak dan menentukan statistik yang akan digunakan selanjutnya. Uji normalitas dalam penelitian ini menggunakan test of normality dari ShapiroWilk dengan software SPSS 22 dimana taraf signifikasinya yaitu 5\% $(0,05)$. Kriteria uji normalitas adalah $H_{0}$ diterima jika nilai sig. $\geq$ 0,05 dan $H_{0}$ ditolak jika nilai sig. < 0,05. Adapun hasil pengolahan data dengan test of normality dari ShapiroWilk sebagai berikut:

Tabel 5.

Hasil Uji Normalitas Distribusi Populasi Data Indeks Gain

\begin{tabular}{|lrl|}
\hline \multicolumn{1}{c}{ Kelas } & \multicolumn{2}{c}{ ShapiroWilk } \\
\cline { 2 - 3 } \multicolumn{1}{c|}{ Eksperimen } & 0,129 & \multicolumn{1}{c|}{ Keterangan } \\
Data indeks gain \\
kentrol & 0,000 & $\begin{array}{l}\text { Data indeks gain } \\
\text { berdistribusi tidak }\end{array}$ \\
\hline
\end{tabular}

normal.

Berdasarkan hasil uji normalitas distribusi populasi yang terdapat pada Tabel 5 diperoleh nilai signifikansi untuk kelas eksperimen sebesar 0,129 atau lebih dari 0,05 maka $H_{0}$ diterima. Keismpulannya, data sampel kelas eksperimen berdistribusi normal. Sedangkan untuk kelas kontrol memperoleh nilai signifikansi sebesar 0,000 atau kurang dari 0,05, maka $H_{0}$ ditolak Diperoleh kesimpulan bahwa data sampel kelas kontrol tidak berdistribusi normal, maka analisis data dilanjutkan dengan uji mann-whitney dengan menggunakan software SPSS 22.

b. Uji Mann-Whitney Data Indeks Gain

Uji Mann-Whitney dalam penelitian ini menggunakan SPSS 22 dimana taraf signifikasinya yaitu 5\% $(0,05)$. Tujuan dilakukannya uji Mann-Whitney yaitu untuk melihat mana yang lebih baik antara peningkatan kemampuan berpikir kreatif matematis siswa dengan menggunakan game education berbantuan android dengan pembelajaran biasa. Kriteria uji Mann-Whitney adalah $H_{0}$ diterima jika nilai sig. $\geq 0,05$ dan $H_{0}$ ditolak jika nilai sig. $<0,05$. Adapun hasil pengolahan data Mann-Whitney sebagai berikut:

Tabel 6.

Hasil Mann-Whitney Distribusi Populasi Data Indeks

$$
\text { Gain }
$$

\begin{tabular}{cc}
\hline Asymp. Sig. (2-tailed) & Keterangan \\
\hline 0,000 & $H_{0}$ ditolak
\end{tabular}

Berdasarkan hasil uji Mann-Whitney pada Tabel 6, diperoleh nilai signifikansi untuk Asymp. Sig. (2-tailed) sebesar 0,000 atau kurang dari 0,05, maka $H_{0}$ ditolak. Diperoleh kesimpulannya bahwa peningkatan kemampuan berpikir kreatif matematis siswa yang belajar dengan game education 
berbantuan android lebih baik dari pada siswa yang belajar dengan pembelajaran biasa.

\section{B. Pembahasan}

Berdasarkan hasil pengolahan data pretest diperoleh bahwa nilai rata-rata kelas eksperimen lebih tinggi dibandingkan kelas kontrol, tetapi selisihnya relatif kecil. Data tersebut diperkuat dari pengujian statistik uji mann whitney yang menggambarkan bahwa tidak terdapat perbedaan kemampuan awal berpikir kreatif matematis antara siswa kelas eksperimen dan siswa kelas kontrol. Oleh karena itu, untuk memperlihatkan peningkatan kemampuan berpikir kreatif matematis siswa terhadap pembelajaran dapat dilihat dari hasil pengelolahan data indeks gain.

Pengolahan data indeks gain kemampuan berpikir kreatif matematis siswa menggambarkan bahwa peningkatan kemampuan berpikir kreatif matematis siswa kelas eksperimen lebih baik dibandingkan dengan siswa kelas kontrol. Dengan kata lain peningkatan kemampuan berpikir kreatif matematis siswa yang mendapatkan pembelajaran dengan game education berbantuan android lebih baik dari pada siswa yang mendapatkan pembelajaran biasa.

Peningkatan kemampuan berpikir kreatif dapat dilakukan dengan berbagai cara yang menyenangkan dan efisien. Teknologi berhasil membantu siswa dalam menyelesaikan soalsoal yang sulit dan memerlukan daya juang yang tinggi (Septian, Komala, \& Komara, 2019; Utomo, Rahman, \& Fikrati, 2020). Kemampuan berpikir kreatif ini berkaitan dengan bagaimana siswa mengembangkan ide-ide baru yang dimilikinya (Faturohman \& Afriansyah, 2020). Permainan bersifat menyenangkan sehingga memicu adanya partisipasi aktif dari siswa untuk belajar (Azka,
Hiltrimartin, \& Indaryatin, 2016; Yuliati, Siregar, \& Sari, 2017). Diperkuat oleh (Oktaviani, Sulistya Dewi, \& ., 2019) yang menyatakan game dapat dilakukan saat pembelajaran dan efektif mengatasi kejenuhan, sehingga siswa merasa tidak kaku dalam belajar matematika.

Peran game education berbantuan android ini dominan mengubah image siswa tentang matematika yang sulit. Kreatifitas siswa tergali dengan baik (Kidi et al., 2017). Padahal materi yang disajikan tidak terlalu mudah untuk disampaikan oleh guru yaitu barisan dan deret (Wahyuni, Rahmad, \& Nasir, 2016; Septiahani, Melisari, \& Zanthy, 2020). Efektifitas cara yang digunakan menjadikan pola perubahan cara berpikir siswa dalam menyelesaikan soal yang non rutin menjadi terbuka dan pantang menyerah (Afriansyah, 2012; Suwarman, 2017). Keberhasilan penggunaan game education berbantuan andorid ini juga menjadikan siswa dan guru menjadi terbuka wawsan tentang makna belajar dengan menyenangkan (Pratama \& Setyaningrum, 2018).

\section{Penutup}

Berdasarkan hasil analisis dan pembahasan diperoleh kesimpulan bahwa peningkatan kemampuan berpikir kreatif matematis siswa yang memperoleh education game berbantuan android lebih baik dibandingkan siswa yang memperoleh pembelajaran biasa. Dengan begitu, disarankan kepada siswa dan guru kelas XI MAN 1 Cianjur untuk dapat memanfaatkan teknologi sebagai media pembelajaran. Selain itu, disarankan juga untuk dilakukannya penelitian lanjutan pada materi lain sehingga terdapat pengembangan dari penelitian ini. Terakhi, penelitian dengan bantuan media pembelajaran education game 
ini disarankan untuk dilanjutkan dengan subjek penelitian yang lebih luas, misal SMA, SMK, maupun perguruan tinggi.

\section{UCAPAN TERIMA KASIH}

Kepada Madrasah Aliyah Negeri 1 Cianjur penulis ucapkan terima kasih sebesarbesarnya atas kerjasama dalam penelitian ini.

\section{DAfTAR Pustaka}

Afriansyah, E. A. (2012). Design Research: Konsep Nilai Tempat pada Penjumlahan Bilangan Desimal (Doctoral dissertation, Tesis yang tidak dipublikasikan berasal dari Beasiswa DIKTI dengan program IMPOME (International Master Program on Mathematics Education). Universitas Sriwijaya Palembang-Universitas UTRECHT Belanda).

Afriansyah, E. A. (2015). Students' Misconception in Decimal Numbers. In International Seminar on Teacher Education 1st ISTE UIN Suska Riau.

Afriansyah, E. A. (2016). Penggunaan software ATLAS. ti sebagai alat bantu proses analisis data kualitatif. Mosharafa: Jurnal Pendidikan Matematika, 5(2), 53-63.

Azka, D. A., Hiltrimartin, C., \& Indaryanti, I. (2016). Pembelajaran Operasi Perkalian melalui Permainan Tepuk Bergambar pada Siswa Tunagrahita Ringan di YPAC Palembang. Mosharafa:

Jurnal

Pendidikan Matematika, 5(1), 26-32.

Dewi, S. S. S., \& Afriansyah, E. A. (2018). Kemampuan Komunikasi Matematis Siswa Melalui Pembelajaran CTL. JIPMat, 3(2), 145-155.

Faturohman, I., \& Afriansyah, E. A. (2020). Peningkatan Kemampuan Berpikir Kreatif Matematis Siswa melalui Creative Problem Solving. Mosharafa: Jurnal Pendidikan Matematika, 9(1), 107-118.

Febriani, S., \& Ratu, N. (2018). Profil proses berpikir kreatif matematis siswa dalam pemecahan masalah open-ended berdasarkan teori Wallas. Mosharafa: Jurnal Pendidikan Matematika, 7(1), 3950.

Firdausi, Y. N., \& Asikin, M. (2018). Analisis Kemampuan Berpikir Kreatif Siswa Ditinjau dari Gaya Belajar pada Pembelajaran Model Eliciting Activities ( MEA ). FMIPA, Universitas Negeri Semarang, Semarang, 1, 239-247.

Florayu, B., Isnaini, M., \& Testiana, G. (2017). Pengaruh Penggunaan Media Pembelajaran Komik terhadap Peningkatan Hasil Belajar Matematika Siswa Kelas VII di Sekolah Menengah Pertama Negeri 10 Palembang. Mosharafa: Jurnal Pendidikan Matematika, 6(1), 45-56.

Fu'adiah, D. (2016). Profil Penalaran Kuantitatif Siswa SMP Ditinjau dari Gender. Mosharafa: Jurnal Pendidikan Matematika, 5(2), 64-74.

Hader, A. E. (2017). Pengaruh Penerapan Model Pembelajaran Student Facilitator And Explaining pada Mata Kuliah Pendidikan Matematika Anak Usia Dini terhadap Keaktifan Mahasiswa Program Studi PGPAUD Universitas Dharmas Indonesia. Mosharafa: Jurnal Pendidikan Matematika, 6(2), 305-310.

Haq, C. N. (2012). Training by Doing. Mosharafa: Jurnal Pendidikan Matematika, 1(1), 43-50.

Hendriawan, M. A., \& Septian, A. (2019). Pengembangan JiMath Sebagai Multimedia Pembelajaran Matematika Berbasis Android Untuk Siswa Sekolah Menengah Atas. IndoMath: Indonesia Mathematics Education, 2(1), 45. https://doi.org/10.30738/indomath.v2i1. 2785

Hockly, N. (2013). Mobile learning. ELT Journal, 67(1), 80-84. https://doi.org/10.1093/elt/ccs064

Hodiyanto, H., Darma, Y., \& Putra, S. R. S. (2020). Pengembangan Media 
Pembelajaran Berbasis Macromedia Flash Bermuatan Problem Posing terhadap Kemampuan Pemecahan Masalah Matematis. Mosharafa: Jurnal Pendidikan Matematika, 9(2), 323-334.

Inayah, S., Septian, A., \& Suwarman, R. F. (2020). Student Procedural Fluency in Numerical Method Subjects. Desimal: Jurnal Matematika, 3(1), 53-64. https://doi.org/10.24042/djm.v3i1.5316

Kementerian Pendidikan dan Kebudayaan Republik Indonesia. (2013). Peraturan Menteri Pendidikan dan Kebudayaan No. 68 tahun 2013 tentang Kerangka Dasar Dan Struktur Kurikulum Sekolah Menengah Pertama/Madrasah Tsanawiyah. PERMENDIKBUD, (Jakarta, Kemendikbud).

https://doi.org/10.1017/CBO9781107415 324.004

Kidi, N., Kanigoro, B., Salman, A. G., Prasetio, Y. L., Lokaadinugroho, I., \& Sukmandhani, A. A. (2017). Android Based Indonesian Information Culture Education Game. Procedia Computer Science, 116, 99-106. https://doi.org/10.1016/j.procs.2017.10. $\underline{015}$

Komariah, I., \& Sundayana, R. (2017). Meningkatkan Aktivitas Belajar Matematika Siswa dengan Menggunakan Media Domat. Mosharafa: Jurnal Pendidikan Matematika, 6(3), 323-332.

Latifah, D., \& Madio, S. S. (2014). Meningkatkan Kemampuan Pemecahan Masalah Matematis Siswa Melalui Model Pembelajaran Missouri Mathematics Project (MMP). Mosharafa: Jurnal Pendidikan Matematika, 3(3), 159-168.

Lestari, T. P., \& Sofyan, D. (2013). Perbandingan Kemampuan Proses Pemecahan Masalah antara Siswa yang Menggunakan Pembelajaran Creative Problem Solving (Cps) dan Konvensional. Mosharafa: Jurnal Pendidikan Matematika, 2(3), 179-190.

Lisnani \& Pranoto, Y. H. (2020). Peningkatan Pemahaman Konsep Bilangan Bulat
Melalui Cerita Si Unyil Berbasis ICT. Mosharafa: Jurnal Pendidikan Matematika, 9(2), 215-226.

Mardiani, D. (2018). Kemampuan Mahasiswa Memahami Persamaan Diferensial Bernauli melalui Model Pembelajaran Game Menempel Nama. Mosharafa: Jurnal Pendidikan Matematika, 7(1), 95102.

Mayasari, Y. (2016). Kemampuan Koneksi Matematis Siswa Melalui Model Pembelajaran Berbasis Masalah (Studi Penelitian di SMP Negeri 5 Garut). Jurnal Riset Pendidikan, 2(01), 27-44.

Muhammad, G. M., Septian, A., \& Sofa, M. I. (2018). Penggunaan Model Pembelajaran Creative Problem Solving untuk Meningkatkan Kemampuan Pemecahan Masalah Matematis Siswa. Mosharafa: Jurnal Pendidikan Matematika, 7(3), 315-326.

https://doi.org/10.31980/mosharafa.v7i3 .140

Nadz, T. F. (2013). Pembelajaran Melalui Metode Problem Based Instruction ( Pbi ) Dengan Metode Konvensional. Mosharafa: Jurnal Pendidikan Matematika, 2(September), 191-202. Retrieved from https://journal.institutpendidikan.ac.id/in dex.php/mosharafa/article/view/mv2n3_ $5 / 212$

Nopiyani, D., Turmudi, T., \& Prabawanto, S. (2018). Penerapan Pembelajaran Matematika Realistik Berbantuan GeoGebra untuk Meningkatkan Kemampuan Komunikasi Matematis Siswa SMP. Mosharafa: Jurnal Pendidikan Matematika, 5(2), 45-52. https://doi.org/10.31980/mosharafa.v5i2 .259

Nurhikmayati, I., \& Sunendar, A. (2020). Pengembangan Project Based Learning Berbasis Kearifan Lokal Berorientasi pada Kemampuan Berpikir Kreatif dan Kemandirian Belajar. Mosharafa: Jurnal Pendidikan Matematika, 9(1), 1-12. 
OECD. (2018). Colombia - Country Note - PISA 2018 Results. In Colombia - Country Note - PISA 2018 Results. Retrieved from https://www.oecd.org/pisa/publications/ PISA2018_CN_COL.pdf

Oktaviani, T., Sulistya Dewi, E. R., \& . K. (2019). Penerapan Pembelajaran Aktif Dengan Metode Permainan Bingo Untuk Meningkatkan Hasil Belajar Matematika. Mimbar IImu, 24(1). https://doi.org/10.23887/mi.v24i1.17409

Pamungkas, Y., \& Afriansyah, E. A. (2017). Aptitude Treatment Interaction terhadap Kemampuan Pemahaman Matematis Siswa. Jurnal Pendidikan Matematika RAFA, 3(1), 122-130.

Pangestu, N. S., \& Yunianta, T. N. H. (2019). Proses Berpikir Kreatif Matematis Siswa Extrovert dan Introvert SMP Kelas VIII Berdasarkan Tahapan Wallas. Mosharafa: Jurnal Pendidikan Matematika, 8(2), 215226.

Permatasari, N. Y., \& Margana, A. (2014). Meningkatkan Kemampuan Siswa dalam Memecahkan Masalah Matematika dengan Model Pembelajaran Treffinger. Mosharafa: Jurnal Pendidikan Matematika, 3(1), 32-42.

Pitriani, R., \& Afriansyah, E. A. (2016). Persepsi dalam pembelajaran pendekatan keterampilan proses terhadap kemampuan koneksi matematis siswa (Studi penelitian di SMP Negeri 1 Wanraja). Jurnal Gantang, 1(2), 15-24.

Pramuditya, S. A., Noto, M. S., \& Purwono, H. (2018). Desain Game Edukasi Berbasis Android pada Materi Logika Matematika. JNPM (Jurnal Nasional Pendidikan Matematika), 2(2), 165. https://doi.org/10.33603/jnpm.v2i2.919

Pratama, L. D., \& Setyaningrum, W. (2018). Game-Based Learning: The effects on student cognitive and affective aspects. Journal of Physics: Conference Series, 1097(1). https://doi.org/10.1088/17426596/1097/1/012123
Rahmawati, N. I. (2018). Pemanfaatan ICT dalam Meningkatkan Kemampuan Literasi Matematika. PRISMA, 1, 381387.

Restiana, N., \& Pujiastuti, H. (2019). Pengukuran Technological Pedagogical Content Knowledge untuk Guru Matematika SMA di Daerah Tertinggal. Mosharafa: Jurnal Pendidikan Matematika, 8(1), 83-94.

Sulastri, S., \& Haq, C. N. (2013). Perbedaan Kemampuan Komunikasi Matematik Siswa antara yang Mendapatkan Model Pembelajaran Jigsaw dan Cooperative Script. Mosharafa: Jurnal Pendidikan Matematika, 2(2), 111-122.

Septiahani, A., Melisari, M., \& Zanthy, L. S. (2020). Analisis Kesalahan Siswa SMK dalam Menyelesaikan Soal Materi Barisan dan Deret. Mosharafa: Jurnal Pendidikan Matematika, 9(2), 311-322.

Septian, A., Darhim, \& Prabawanto, S. (2020). Geogebra in integral areas to improve mathematical representation ability Geogebra in integral areas to improve mathematical representation ability. Journal of Physics: Conference Series, 1613(2020).

https://doi.org/10.1088/17426596/1613/1/012035

Septian, A., Komala, E., \& Komara, K. A. (2019). Pembelajaran dengan Model Creative Problem Solving (CPS)untuk Meningkatkan Kemampuan Berpikir Kreatif Matematis Siswa. 8(2), 182-190.

Sugilar, H. (2013). Meningkatkan Kemampuan Berpikir Kreatif dan Disposisi Matematik Siswa Madrasah Tsanawiyah melalui Pembelajaran Generatif. Infinity Journal, 2(2), 156-168. https://doi.org/10.22460/infinity.v2i2.32 Suripah, S., \& S. A. (2017). Kemampuan Berpikir Kreatif Matematis Mahasiswa dalam Menyelesaikan Akar Pangkat Persamaan Kompleks Berdasarkan Tingkat Kemampuan Akademik. Jurnal 
Pendidikan Matematika, 12(2), 149-160.

https://doi.org/10.21831/pg.v12i2.16509

Suryadi, A. (2015). Sistem Pengenalan Wajah

Menggunakan Metode Principal

Component Analysis (Pca) Dengan

Algoritma Fuzzy C-Means

(Fcm). Mosharafa: Jurnal Pendidikan Matematika, 4(2), 58-65.

Suwarman, R. F. (2017). Pengaruh Model Pembelajaran Auditory, Intellectually, Repetition (AIR) terhadap Peningkatan Pemecahan Masalah Matematis Siswa. PRISMA, 6(2).

https://doi.org/10.35194/jp.v6i2.58

Suwarto, S. (2018). Analisis Kesulitan Belajar Operasi Hitung pada Siswa Kelas Satu Sekolah Dasar. Mosharafa: Jurnal Pendidikan Matematika, 7(2), 285-294.

Tarlina, W. H., \& Afriansyah, E. A. (2016). Kemampuan Berpikir Kreatif Siswa Melalui Creative Problem Solving. Eduma: Mathematics Education Learning and Teaching, 5(2), 42-51.

Tarusu, D. T. (2018). Kemampuan pedagogik matematika SD pada mahasiswa PGSD FIP UNIMA. Mosharafa: Jurnal Pendidikan Matematika, 7(2), 263-272.

Utomo, E. S., Rahman, F., \& Fikrati, A. N. (2020). Eksplorasi Penalaran Logis Calon Guru Matematika Melalui Pengintegrasian Pendekatan STEM dalam Menyelesaikan Soal. Mosharafa: Jurnal Pendidikan Matematika, 9(1), 13-22.

Wahyuni, S., Rahmad, M., \& Nasir, M. (2016).

Penerapan Model Pembelajaran Creative Problem Solving Pada Materi Listrik Dinamis Untuk Meningkatkan Keterampilan generik Sains Siswa kelas $X$ SMAN 1 Tambusai Utara. Jurnal Online Mahasiswa Bidang Keguruan Dan IImu Pendidikan, 3(2), 1-12.

Yuliati, S. R., Siregar, R., \& Sari, R. P. (2017). Permainan Polydron Dalam Proses Pembelajaran Matematika Di Sekolah Dasar. PARAMETER: Jurnal Pendidikan Universitas Negeri Jakarta, 29(2), 223-
230.

https://doi.org/10.21009/parameter.292.

10.

\section{Riwayat Hidup Penulis Asri Muslim Sanusi}

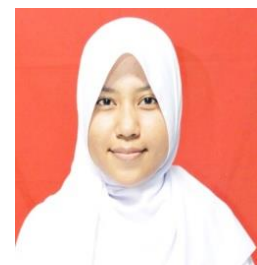

Lahir di Cianjur pada tanggal 24 Juni 1997. Penulis merupakan anak Ke dua dari 5 bersodara. Saat ini penulis beralamat di $\mathrm{kp}$ baru Pawenang RT/01 RW/23 Kel. Muka Kec. Cianjur Kab Cianjur, Jawa Barat. Sedang studi S1 di Universitas Suryakancana Cianjur sebagai mahasiswa Fakultas Keguruan dan Ilmu Pendidikan (FKIP) Program Studi pendidikan Matematika.

Ari Septian, S. Si., M. Pd.

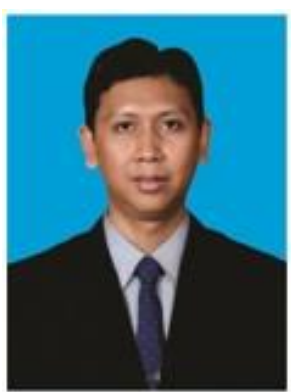

Lahir di Cianjur pada tanggal 12 September 1985. Penulis adalah dosen sekaligus ketua Program Studi Pendidikan Matematika, Fakultas Keguruan dan Ilmu Pendidikan Universitas Suryakancana. Penulis menempuh Studi S1 bidang matematika di Institut Pertanian Bogor, lulus pada tahun 2008. Studi S2 bidang pendidikan matematika di Universitas Pasundan, lulus pada tahu 2012. Sekarang sedang melanjutkan studi S3 bidang pendidikan matematika di Universitas Pendidikan Indonesia.

\section{Sarah Inayah, S. Pd., M. Pd.}

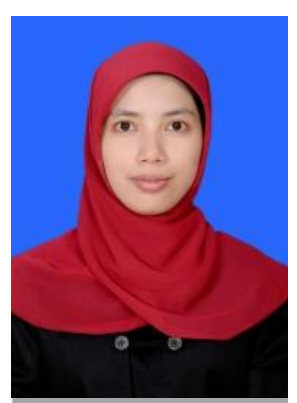

Lahir di Cianjur, 15 Februari 1988. Penulis adalah dosen di program studi pendidikan matematika, Fakultas Keguruan dan IImu Pendidikan Universitas Suryakancana Cianjur. Studi S1 bidang pendidikan matematika di Universitas Suryakancana Cianjur, tahun lulus 2010. Studi S2 bidang pendidikan matematika di Universitas Pendidikan Indonesia, Bandung, tahun lulus 2013. 